\title{
Genetic parameters and trends for birth weight, birth coat score and weaning weight in Merino lines divergently selected for ewe multiple rearing ability
}

\author{
S.W.P. Cloete ${ }^{1,2 \#}$, J.J. Olivier ${ }^{3}$, J.B. van Wyk $^{1}$, G.J. Erasmus ${ }^{1}$ and S.J. Schoeman ${ }^{4}$ \\ ${ }^{1}$ University of the Free State, PO Box 339, Bloemfontein 9300, South Africa \\ ${ }^{2}$ Elsenburg Agricultural Development Centre, Private Bag X1, Elsenburg 7607, South Africa \\ ${ }^{3}$ Irene Animal Improvement Institute, Private Bag X5013, Stellenbosch 7599, South Africa \\ ${ }^{4}$ University of Stellenbosch, Private Bag X1, Matieland 7602, South Africa
}

\begin{abstract}
Data were recorded for birth weight, birth coat score and weaning weight of between 2018 and 4235 Merino lambs born over a 17-year interval from 1986 to 2002. The resource population was divergently selected from the same base population since 1986, either for (H line) or against (L line) maternal multiple rearing ability. Direct additive genetic variances - expressed as a ratio of the total phenotypic variance $\left(\mathrm{h}^{2}\right.$, direct heritability) - were estimated at $0.12 \pm 0.03$ for birth weight, $0.70 \pm 0.05$ for birth coat score and 0.13 \pm 0.04 for weaning weight. Maternal genetic variance ratios $\left(\mathrm{m}^{2}\right)$ were estimated at $0.23 \pm 0.04$ for birth weight and $0.10 \pm 0.04$ for weaning weight. It was not significant for birth coat score. Maternal permanent environmental variance ratios $\left(\mathrm{c}^{2}\right)$ for the respective traits amounted to $0.08 \pm 0.03$ for birth weight, $0.04 \pm$ 0.02 for birth coat score and $0.08 \pm 0.03$ for weaning weight. No consistent phenotypic or genetic differences in favour of either line were found for birth weight or birth coat score. Compared to L line lambs, phenotypic means for weaning weight were heavier in favour of $\mathrm{H}$ line lambs from 1995. This trend was confirmed by divergence in yearly averaged direct breeding values in the $\mathrm{H}$ and $\mathrm{L}$ lines. Expressed as percentage of the overall phenotypic mean for weaning weight, genetic changes amounted to $+0.23 \%$ in the $\mathrm{H}$ line and $-0.26 \%$ in the $\mathrm{L}$ line. A corresponding maternal genetic trend amounting to $-0.19 \%$ of the overall phenotypic mean for weaning weight was found in the L line, while no maternal genetic change could be discerned in the $\mathrm{H}$ line. Divergent selection for multiple rearing ability thus did not influence birth weight and birth coat score, while the correlated response in weaning weight was favourable.
\end{abstract}

Keywords: Direct heritability, genetic trends, maternal heritability, parameter estimation, smoothing splines ${ }^{\#}$ Corresponding author. E-mail: schalkc@elsenburg.com

\section{Introduction}

Production in sheep reflects the genes that an animal has inherited from both its parents as well as a mixture of seasonal and husbandry factors peculiar to the environment an animal finds itself in (Lewis \& Beatson, 1999). Maternal influences are evident early in the life of lambs, while it tends to disappear with an increase in age (Snyman et al., 1995). Maternal influences can be derived from the genotype of the dam (maternal additive genetic effects) and those consistent between lambings but not genetic in origin, also referred to as maternal permanent environmental effects (Lewis \& Beatson, 1999). The advent of sophisticated software enables analysts to fit extended models to data obtained from livestock breeding operations (Meyer, 1989).

This paper reports genetic and environmental influences on live weight at birth and weaning, as well as on birth coat score in a Western Cape Merino resource flock. The flock has been subjected to divergent selection based on maternal multiple rearing ability (Cloete \& Scholtz, 1998). Preliminary analysis indicated genetic divergence between the lines in several traits of economic importance (Cloete \& Olivier, 1998). Birth coat score has so far not been assessed in a genetic analysis on South African Merinos. The trait is reported to be highly heritable (Ponzoni et al., 1996; Kemper et al., 2003), while it may also be related to the thermo-regulating ability of lambs (Alexander, 1964). In this sense it may be of value as far as the prevention of lamb mortality is concerned (Purser \& Karam, 1967; Obst \& Evans, 1970). Since differential levels of lamb mortality were found between the two lines under study (Cloete \& Scholtz, 1998; Cloete, 2002), the resource population was considered to be extremely suitable for the study of genetic aspects of birth coat score. 


\section{Material and Methods}

Two lines of Merino sheep were divergently selected from the same base population since 1986, using maternal ranking values for lambs reared per joining. Details of the selection procedure of replacements can be found in the literature (Cloete \& Scholtz, 1998). In short, ewe and ram progeny of ewes rearing more than one lamb per joining (i.e. reared twins at least once) were preferred as replacements in the High $(\mathrm{H})$ line. Replacements were preferably descended from ewes rearing fewer than one lamb per joining (i.e. barren or lost all lambs born at least once) in the Low (L) line. Depending on the average reproduction of the lines and the replacement needs, progeny of ewes that reared one lamb per joining were occasionally accepted in both lines. Selection decisions were mostly based on $\geq 3$ maternal joinings, especially in the case of rams. Once selected, ewes normally remained in the breeding flock for five joinings, except for cases of death and teeth or udder malfunction. No selection on reproduction was thus directed at the current flock. The $\mathrm{H}$ line was augmented by 28 ewes from a multiple ovulation and embryo transfer program, that were born during 1991 and 1992 (Cloete et al., 1998). Progeny of 6-year-old ewes screened into the respective lines from other lines were also available since the 1996 lambing season. The screening process was detailed by Cloete (2002).

The two lines were maintained as a single flock, at first at the Tygerhoek experimental farm for the interval from 1986 to 1992. At the end of 1992 the animals were transferred to Elsenburg for studies on lambing behaviour (Cloete \& Scholtz, 1998; Cloete, 2002). During this period the lines were also kept in a single flock, except during joining in single sire groups to 4-6 rams. Further treatment of the experimental animals was fairly similar on both farms, except for the lambing season. At Tygerhoek ewes were handmated in spring to lamb during autumn (March - April) of the following year. At Elsenburg joining took place in summer, for lambing during the winter (June - July) of the same year. Dryland lucerne (Medicago sativa) and medic (M. truncatula) pastures were mostly utilised on both localities. Small grain fodder crops (mostly oats) were occasionally utilised in winter, while small grain crop residues and oat standing hay were seasonally available during spring and early summer. At Elsenburg, irrigated kikuyu (Pennisetium clandestinum) paddocks were utilised during joining and lambing (Cloete \& Scholtz, 1998).

Lamb birth weight was recorded within 24 hours of birth, as described by Cloete \& Scholtz (1998). Birth coat score was scored on a linear scale, taking cognisance of halo hair and short, curly, woolly groups of fibres (Ponzoni et al., 1996). The scale was as follows: 1 - Hairy; 2 - More hairy than woolly; 3 Equally hairy and woolly; 4 - More woolly than hairy; 5 - Woolly. Half marks were given in cases where it was impossible to judge differences between adjacent classes. Weaning weight was recorded at an age of approximately 3.5 months, and corrected to an age of 100 days prior to analysis. The correction procedure described by Van der Merwe (1976) was applied. Environmental factors affecting the production traits included year of birth (1986-2002), gender (male or female), age of dam (2 to 7+ years) and birth type (single or pooled multiples). The identity of the sire and dam of lambs was known individually. This information enabled linkage back to the line they were born in.

The ASREML program (Gilmour et al., 1999) was used for the analysis of the fixed effects, and also subsequently to estimate variance components in univariate analyses. The first analysis involved fitting various combinations of fixed effects to obtain an operational model, including linear trends in year and age of dam means. Random trends other than linear in year and age of dam means, as well as random deviations from linearity but not conforming to a smooth curve, were also fitted where applicable at this stage (Verbyla et al., 1999). Effects found to be significant $(\mathrm{P}<0.05)$ in these preliminary analyses were included in subsequent analyses. Random terms were then added to the operational model, resulting in the following models for analyses (in matrix notation):

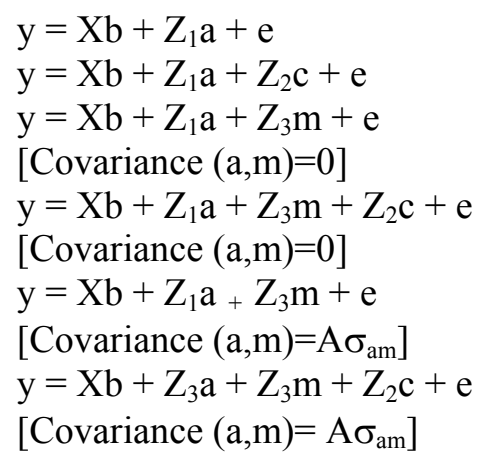


In these analyses, $y$ was a vector of observations for birth weight, birth coat score or weaning weight, and $b, a, m$ and $c$ vectors of fixed effects, direct genetic variances, maternal genetic variances and maternal permanent environmental variances respectively. $X, Z_{1}, Z_{2}$ and $Z_{3}$ were the corresponding incidence matrices relating the respective effects to $y$, while e was the vector of residuals. A was the numerator relationship matrix, and $\sigma_{\mathrm{am}}$ the covariance between direct genetic and maternal genetic effects.

It was assumed that:

$$
\mathrm{V}(\mathrm{a})=\mathrm{A} \sigma_{\mathrm{a}}^{2} ; \mathrm{V}(\mathrm{m})=\mathrm{A} \sigma_{\mathrm{m}}^{2} ; \mathrm{V}(\mathrm{c})=\mathrm{I} \sigma_{\mathrm{c}}^{2} ; \mathrm{V}(\mathrm{e})=\mathrm{I} \sigma_{\mathrm{e}}^{2},
$$

with I being identity matrixes; $\sigma_{\mathrm{a}}^{2}, \sigma_{\mathrm{m}}^{2}, \sigma_{\mathrm{c}}^{2}$ and $\sigma_{\mathrm{e}}^{2}$ the direct genetic variance, maternal genetic variance and the maternal permanent environmental variance and environmental (residual) variance, respectively. These analyses yielded estimates of genetic and permanent environmental variances. Ratios for direct additive genetic, maternal genetic as well as maternal permanent environmental variances were computed from these estimates. These variances were expressed relative to the total phenotypic variance. Log likelihood tests were conducted to determine the most suitable model for each trait in uni-variate analyses (Snyman et al., 1996). Subsequently, 2-trait animal models were fitted, allowing the calculation of all relevant direct and maternal correlations between traits, together with the appropriate standard errors.

BLUP of direct and maternal breeding values for traits were obtained where applicable and averaged within birth years. Genetic trends derived in this way were inspected for divergence between lines, using standard errors obtained for the regression coefficients. Breeding values were obtained from analyses where selection line and its interactions with other traits were excluded from the operational models.

\section{Results}

Overall, lamb birth weight was independent of selection line $(\mathrm{P}>0.10$; Table 1). Selection line interacted with both the linear component of the spline for birth year, as well as random deviations from linearity $(\mathrm{P}<0.05)$. Phenotypic means for birth weight ranged between $2.9 \mathrm{~kg}$ and $3.9 \mathrm{~kg}$ for the period from 1986 to 1992 (Figure 1). After 1992 means appeared to stabilise at a slightly higher level, between 3.8 $\mathrm{kg}$ and $4.3 \mathrm{~kg}$. Birth weight phenotypic means generally did not differ between lines prior to 1993 . Lambs in the $\mathrm{H}$ line tended to be heavier $(\mathrm{P}<0.10)$ at birth than $\mathrm{L}$ line lambs from 1993 to 1997 . No subsequent line differences were found. Ram lambs and singles were respectively 6.7 and $27.8 \%$ heavier $(\mathrm{P}<0.01)$ than ewes and multiples (Table 1). Lamb birth weight increased curvi-linearly $(\mathrm{P}<0.01)$ with an increase in dam age, reaching a maximum in 4 to 6 year-old dams.

Table 1 Least squares means ( \pm s.e.) for birth weight, birth coat score and weaning weight in lambs of the $\mathrm{H}$ and $\mathrm{L}$ lines

\begin{tabular}{lccc}
\hline Fixed effects & $\begin{array}{c}\text { Birth weight } \\
(\mathrm{kg})\end{array}$ & $\begin{array}{c}\text { Birth coat score } \\
(\mathrm{n})\end{array}$ & $\begin{array}{c}\text { Weaning weight } \\
(\mathrm{kg})\end{array}$ \\
\hline Number of observations & 4235 & 2018 & 316 \\
Overall mean & $3.85 \pm 0.08$ & $3.22 \pm 0.10$ & $21.8 \pm 0.5$ \\
Birth year & $* *$ & $\mathrm{~ns}$ & $* *$ \\
Selection line & $\mathrm{ns}$ & $\mathrm{ns}$ & $*$ \\
H line & $3.90 \pm 0.09$ & $3.20 \pm 0.12$ & $22.3 \pm 0.5$ \\
L Line & $3.80 \pm 0.09$ & $3.24 \pm 0.14$ & $21.3 \pm 0.5$ \\
Birth type & $* *$ & $\mathrm{~ns}$ & $* *$ \\
Single & $4.32 \pm 0.08$ & $3.18 \pm 0.10$ & $23.6 \pm 0.5$ \\
Multiple & $3.38 \pm 0.08$ & $3.26 \pm 0.10$ & $20.0 \pm 0.4$ \\
Gender & $* *$ & $*$ & $*$ \\
Ram & $3.98 \pm 0.08$ & $3.33 \pm 0.10$ & $22.3 \pm 0.5$ \\
Ewe & $3.73 \pm 0.08$ & $3.11 \pm 0.10$ & $21.3 \pm 0.5$ \\
Age of dam (years $)$ & $* *$ & $\mathrm{~ns}$ & $*$ \\
2 & $3.47 \pm 0.09$ & $3.33 \pm 0.10$ & $20.6 \pm 0.5$ \\
3 & $3.72 \pm 0.08$ & $3.27 \pm 0.10$ & $21.5 \pm 0.5$ \\
4 & $3.85 \pm 0.08$ & $3.23 \pm 0.10$ & $21.8 \pm 0.5$ \\
5 & $3.90 \pm 0.08$ & $3.21 \pm 0.10$ & $21.7 \pm 0.5$ \\
6 & $3.89 \pm 0.08$ & $3.22 \pm 0.09$ & $21.4 \pm 0.5$ \\
7 & $3.80 \pm 0.09$ & $3.25 \pm 0.09$ & $20.9 \pm 0.5$ \\
\hline ns - Not significant $(\mathrm{P}>0.01) ;{ }^{*}$ - Significant $(\mathrm{P}<0.05) ; *$ Significant $(\mathrm{P}<0.01)$ &
\end{tabular}




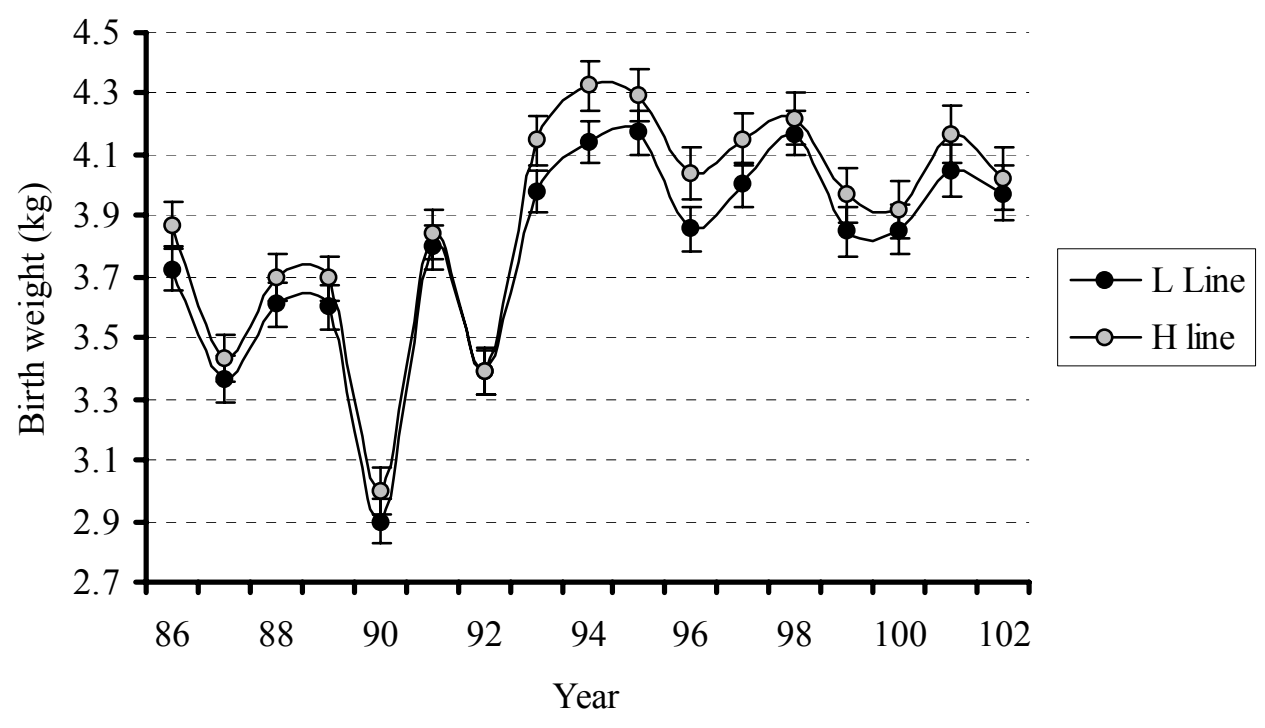

Figure 1 Phenotypic trend for birth weight in the H and L lines for a 17-year period from 1986 to 2002. Vertical bars around the means denote standard errors

Birth coat score was generally independent of the known sources of variation, but for gender (Table 1). Rams had slightly woollier coats than ewes $(\mathrm{P}<0.05)$. Overall, $\mathrm{H}$ line lambs tended $(\mathrm{P}<0.10)$ to be heavier at weaning than L line contemporaries. Selection line once more interacted with both the linear component of the spline for birth year, as well as random deviations from linearity $(\mathrm{P}<0.05)$. Phenotypic means for weaning weight were generally not different at the commencement of the trial (Figure 2), but consistent line differences in favour of the $\mathrm{H}$ line were observed since 1994 . Selection line interacted with birth type for lamb weaning weight. In singles, $\mathrm{H}$ line lambs were $6.9 \%$ heavier than $\mathrm{L}$ line contemporaries ( $24.4 \pm 0.5 \mathrm{~kg}$ vs. $22.9 \pm 0.5 \mathrm{~kg}$ respectively). The corresponding difference in multiples was not significant $(20.1 \pm 0.5 \mathrm{~kg}$ vs. $19.8 \pm 0.5 \mathrm{~kg}$ respectively). Overall, ram lambs and singles were respectively 4.7 and $18.0 \%$ heavier $(\mathrm{P}<0.05)$ than ewes and multiples. Lamb weaning weights increased curvi-linearly $(\mathrm{P}<$ 0.01 ) with an increase in dam age, reaching a maximum in 3 to 5 year-old dams.

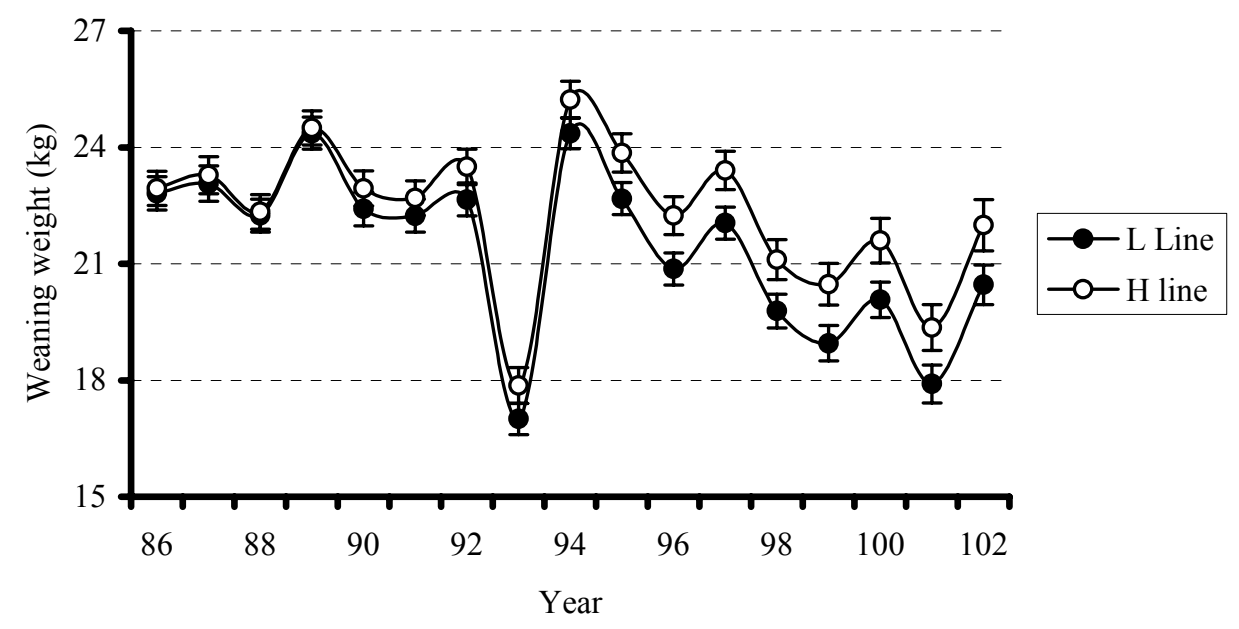

Figure 2 Phenotypic trend for weaning weight in the H and L lines for a 17-year period from 1986 to 2002. Vertical bars around the means denote standard errors

The statistical model of choice included two or more random terms for all three traits (Table 2). Direct additive, maternal additive and maternal permanent environmental variances were included for birth 
weight and weaning weight, while only direct additive and maternal permanent environmental variances were included for birth coat score.

Table 2 Log likelihood ratios for birth weight, birth coat score and weaning weight in Merino lambs of the $\mathrm{H}$ and L lines under seven different models of analysis. The "best' models are denoted in bold, italic figures, and the number of the model fitted are provided in brackets (see Material and Methods)

\begin{tabular}{lccc}
\hline Model fitted & Birth weight & Birth coat score & Weaning weight \\
\hline Fixed effects only & -580.592 & -466.554 & -5699.02 \\
$+\mathrm{h}^{2}(1)$ & -388.743 & -215.657 & -5638.95 \\
$+\mathrm{h}^{2}+\mathrm{c}^{2}(2)$ & -228.475 & $-\mathbf{2 1 1 . 3 1 9}$ & -5605.51 \\
$+\mathrm{h}^{2}+\mathrm{m}^{2}(3)$ & -203.669 & -212.840 & -5604.32 \\
$+\mathrm{h}^{2}+\mathrm{c}^{2}+\mathrm{m}^{2}(4)$ & $\mathbf{- 1 9 9 . 4 2 6}$ & -211.318 & -5600.59 \\
$+\mathrm{h}^{2}+\mathrm{m}^{2}+\mathrm{r}_{\mathrm{am}}(5)$ & -202.319 & -212.816 & -5603.35 \\
$+\mathrm{h}^{2}+\mathrm{c}^{2}+\mathrm{m}^{2}+\mathrm{r}_{\mathrm{am}}(6)$ & -198.449 & -211.270 & -5599.40 \\
\hline
\end{tabular}

Parameter estimates for birth weight were 0.12 for $\mathrm{h}^{2}, 0.23$ for $\mathrm{m}^{2}$ and 0.08 for $\mathrm{c}^{2}$ (Table 3 ). Birth coat score was highly heritable $(0.70)$, with a small $\mathrm{c}^{2}$ component of 0.04 . Direct heritability was estimated at 0.13 for weaning weight, with a $\mathrm{m}^{2}$ estimate of 0.10 and a $\mathrm{c}^{2}$ estimate of 0.08 .

Table 3 Variance components and estimates of the direct genetic $\left(\mathrm{h}^{2}\right)$, maternal genetic $\left(\mathrm{m}^{2}\right)$ and maternal permanent environmental $\left(\mathrm{PE}-\mathrm{c}^{2} \mathrm{PE}\right)$ variance ratios $( \pm$ s.e.) for the traits assessed in Merino lambs of the $\mathrm{H}$ and $\mathrm{L}$ lines

\begin{tabular}{lccc}
\hline Component or ratio & Birth weight & Birth coat score & Weaning weight \\
\hline Variance components & & & \\
Residual $\left(\sigma^{2}\right)$ & 0.2742 & 0.1530 & 9.7858 \\
Direct additive $\left(\sigma^{2}{ }_{\mathrm{a}}\right)$ & 0.0582 & 0.4217 & 1.9006 \\
Maternal additive $\left(\sigma_{\mathrm{m}}^{2}\right)$ & 0.1112 & - & 1.4002 \\
Maternal PE $\left(\sigma^{2}\right)$ & 0.0403 & 0.0269 & 1.1710 \\
Total phenotype $\left(\sigma_{\mathrm{p}}^{2}\right)$ & 0.4839 & 0.6016 & 14.2586 \\
Variance ratios & & & \\
$\mathrm{h}^{2}$ & $0.12 \pm 0.03$ & $0.70 \pm 0.05$ & $0.13 \pm 0.04$ \\
$\mathrm{~m}^{2}$ & $0.23 \pm 0.04$ & - & $0.10 \pm 0.04$ \\
$\mathrm{c}^{2}$ & $0.08 \pm 0.03$ & $0.04 \pm 0.02$ & $0.08 \pm 0.03$ \\
\hline
\end{tabular}

- Effect not significant according to log likelihood ratio

Correlations between birth weight and birth coat score were generally low, variable and smaller than double the corresponding standard errors (Table 4). Inspection of the correlations between weaning weight and birth coat score led to similar conclusions. Birth weight and weaning weight were highly correlated on the direct and maternal genetic levels. Phenotypic and environmental correlations were lower, but still significant $(\mathrm{P}<0.05)$.

Table 4 Direct additive $\left(r_{g}\right)$, maternal additive $\left(r_{m}\right)$, maternal permanent environmental $\left(r_{c}\right)$, environmental $\left(\mathrm{r}_{\mathrm{e}}\right)$ and phenotypic $\left(\mathrm{r}_{\mathrm{p}}\right)$ correlations among traits recorded in $\mathrm{H}$ and $\mathrm{L}$ line lambs

\begin{tabular}{lccc}
\hline Correlation & $\begin{array}{c}\text { Birth weight } \times \text { birth coat } \\
\text { score }\end{array}$ & $\begin{array}{c}\text { Birth weight } \times \text { weaning } \\
\text { weight }\end{array}$ & $\begin{array}{c}\text { Birth coat score } \times \\
\text { weaning weight }\end{array}$ \\
\hline Direct additive $\left(r_{\mathrm{g}}\right)$ & $-0.15 \pm 0.14$ & $0.63 \pm 0.14$ & $0.02 \pm 0.14$ \\
Maternal additive $\left(r_{\mathrm{m}}\right)$ & - & $0.66 \pm 0.13$ & - \\
Maternal PE $\left(\mathrm{r}_{\mathrm{c}}\right)$ & $-0.11 \pm 0.25$ & $0.14 \pm 0.26$ & $-0.27 \pm 0.27$ \\
Environmental $\left(\mathrm{r}_{\mathrm{e}}\right)$ & $0.01 \pm 0.07$ & $0.21 \pm 0.03$ & $-0.06 \pm 0.07$ \\
Phenotypic $\left(\mathrm{r}_{\mathrm{p}}\right)$ & $-0.05 \pm 0.03$ & $0.32 \pm 0.02$ & $-0.04 \pm 0.03$ \\
\hline
\end{tabular}

- Effect not significant according to log likelihood ratio

Genetic trends derived from averaged annual predicted breeding values for the $\mathrm{H}$ and $\mathrm{L}$ lines were divergent $(\mathrm{P}<0.05)$ and symmetric (Figure 3$)$. The genetic trend in the $\mathrm{H}$ line was positive and amounted to 
$0.23 \%$ of the overall phenotypic mean annually $\left(\mathrm{b} \pm\right.$ s.e. $\left.=0.057 \pm 0.005 ; \mathrm{R}^{2}=0.73\right)$. The corresponding downward trend in the L line amounted to $0.26 \%$ of the overall phenotypic mean annually ( $\mathrm{b} \pm$ s.e. $=-0.063$ $\left.\pm 0.009 ; \mathrm{R}^{2}=0.11\right)$. Although this trend was significant $(\mathrm{P}<0.01)$, it did not fit the data very well, as reflected by the low $\mathrm{R}^{2}$-value.

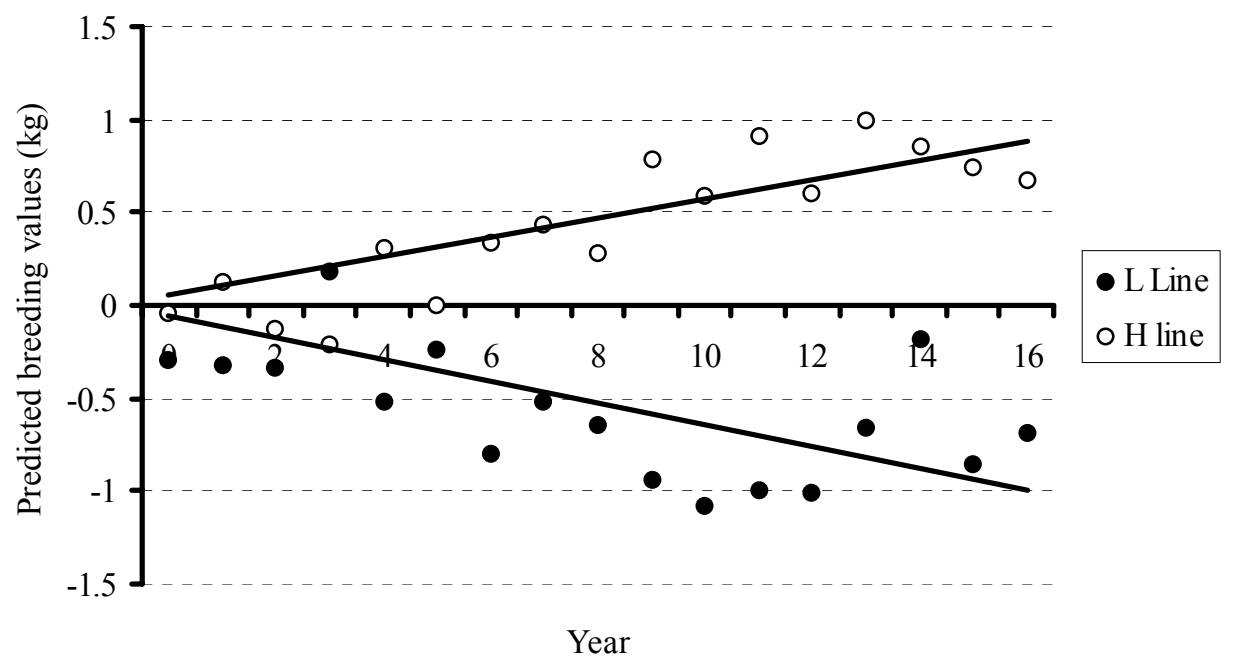

Figure 3 Averaged direct additive breeding values for weaning weight in the $\mathrm{H}$ and $\mathrm{L}$ lines over a 17 -year period. Both graphs were forced through the origin

No significant maternal genetic trend was observed in the $\mathrm{H}$ line (Figure 4). Maternal breeding values for weaning weight in the L line decreased annually at $0.19 \%$ of the overall environmental mean for weaning weight $\left(\mathrm{b} \pm\right.$ s.e. $\left.=-0.046 \pm 0.004 ; \mathrm{R}^{2}=0.34\right)$. Trends for the respective selection lines were divergent $(\mathrm{P}<$ $0.05)$, but asymmetric in this instance.

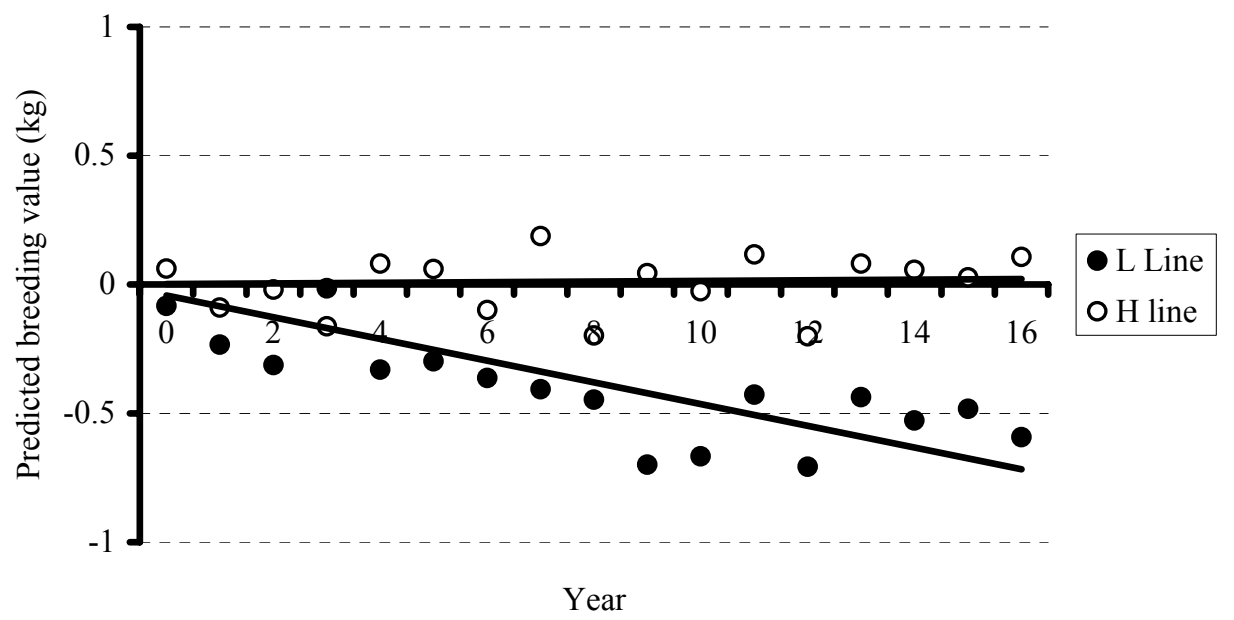

Figure 4 Averaged maternal additive breeding values for weaning weight in the $\mathrm{H}$ and $\mathrm{L}$ lines over a 17-year period. Both graphs were forced through the origin

\section{Discussion}

Although selection line was fitted as a fixed effect in the initial analyses that were conducted, this effect is rather discussed with the random effects. This approach was chosen since it was reasoned that the observed line differences were in response to the selection pressure applied to the respective lines. The effects of gender, birth type and dam age on birth weight and weaning weight were consistent with those 
obtained from comparable data sets in the literature, and not worthy of discussion. It is noteworthy that birth weight in the experiment was generally lower initially, when the resource population was maintained at the Tygerhoek experimental farm (see Cloete \& Scholtz, 1998 for general background). Generally, higher birth weights were recorded in subsequent years, when the population was maintained at Elsenburg. This result is possibly related to the season of lambing used at the respective experimental sites (during autumn at Tygerhoek and during winter at Elsenburg). Winter lambing ewes were previously found to give birth to heavier lambs under Mediterranean conditions than autumn lambing ewes (Cloete et al., 1994).

Birth coat score was independent of the fixed effects included in the analysis, with the exception of gender. Previous results indicated that birth coat score was not largely influenced by non-genetic sources of variation (Davis, 1987b; Ponzoni et al., 1996). Ewes also generally had slightly coarser birth coats than rams in these studies, as was also found in the present study.

Literature results from animal model analyses will generally be considered as far as genetic parameters for birth weight and for weaning weight are concerned. In the case of birth weight, genetic parameters obtained from a wide range of sheep breeds ranged from 0.04 to 0.42 for $\mathrm{h}^{2}, 0.09$ to 0.65 for $\mathrm{m}^{2}$ and from 0.08 to 0.37 for $\mathrm{c}^{2}$ (see summary by Duguma et al., 2002). Our estimates of 0.12 for $\mathrm{h}^{2}, 0.23$ for $\mathrm{m}^{2}$ and 0.08 for $\mathrm{c}^{2}$ accords very well with the range of literature values cited above. Genetic parameters for birth weight are relatively scarce for Merino lambs. In this breed, previous estimates of $\mathrm{h}^{2}$ ranged from 0.18 to 0.23 (Mortimer \& Atkins, 1995; Cloete et al., 2001; Duguma et al., 2002). Corresponding estimates of $\mathrm{m}^{2}$ ranged from 0.14 to 0.25 , and those for $\mathrm{c}^{2}$ from 0.08 to 0.12 . Estimates from the present study accords with these findings. The exception was $\mathrm{h}^{2}$, which tended to be slightly lower than the estimates cited.

Although $\mathrm{H}$ line lambs were phenotypically somewhat heavier $(\mathrm{P}<0.05)$ at birth than $\mathrm{L}$ line contemporaries for a period during the mid-1990's (see also Cloete \& Scholtz, 1998 in this regard), this effect was not consistent. No conclusive line differences were found at the beginning of the experiment and during the latter part of the experiment. Genetic trends derived from direct and maternal breeding values for birth weight similarly did not reflect marked correlated changes in birth weight to divergent selection for maternal multiple rearing ability. Unwanted changes in birth weight leading to either dystocia (as a result of heavier lambs) or poor lamb vigour and ill-thrift (typical of low live weight lambs) thus seems unlikely.

At 0.70 , the obtained heritability estimate of birth coat score was very high. Literature results were in good agreement, ranging from 0.55 to 0.80 (Morley, 1955; Gregory, 1982; Davis, 1987b; Ponzoni et al., 1996). The only recent animal model estimate that was found was a $\mathrm{h}^{2}$ value of 0.65 reported by Kemper et al. (2003). It is evident that fast rates of genetic change in birth coat score are feasible, should it be desired. It was demonstrated in a climate chamber that lambs with hairy birth coats were able to conserve heat more readily than lambs with woolly birth coats (Alexander, 1964). Little evidence of improved survival in hairy lambs was obtained under paddock conditions (Davies, 1964; Mullaney, 1966; Ponzoni et al., 1996). Based on results obtained in a particular year when the weather was particularly unfavourable (Mullaney, 1966), it was contended that an advantage in survival would only become noticable under extremely adverse conditions. This contention was supported by results published subsequently (Purser \& Karam, 1967; Obst \& Evans, 1970). In the present study lambing took place during winter since 1992. Cold spells with windy and rainy weather are common in the Mediterranean winter. It was demonstrated that lambs in the $\mathrm{H}$ line survived markedly better $(\mathrm{P}<0.05)$ than their L line contemporaries during the periods from 1993 to 1997 (Cloete \& Scholtz, 1998) and from 1998 to 2002 (Cloete, 2002). The line difference in survival was particularly marked in multiple lambs (Cloete \& Scholtz, 1998; Cloete, 2002). Despite these differences, birth coat score was similar for the lines (see Table 1), suggesting no marked correlated change. The results from this study therefore supported literature findings that birth coat score is not highly related to lamb survival (Ponzoni et al., 1996). Further studies on birth coat score showed that it was also of little consequence as far as hogget fleece traits (Olivier, 1996; Ponzoni et al., 1996; Kemper et al., 2003) or ewe reproduction (Ponzoni et al., 1996) were concerned.

No line difference in weaning weight was observed in multiple lambs, while $\mathrm{H}$ line lambs were heavier $(\mathrm{P}<0.05)$ at this stage than $\mathrm{L}$ line contemporaries. This interaction can be readily explained by the differential mortality rates in multiple lambs belonging to the respective lines (Cloete \& Scholtz, 1998; Cloete, 2002). Twin and triplet lambs in the $\mathrm{H}$ line were much more likely to be reared as multiples than those born in the L line.

Results summarised from the literature for weaning weight indicated $\mathrm{h}^{2}$ estimates of 0.09 to $0.50, \mathrm{~m}^{2}$ estimates of 0.02 to 0.48 and $\mathrm{c}^{2}$ estimates of 0.06 to 0.20 (Duguma et al., 2002). Respective estimates of $0.13,0.10$ and 0.08 in the present study are well within these ranges. Other studies on Merinos found 
estimates of $\mathrm{h}^{2}$ ranging from 0.14 to 0.30 , estimates of $\mathrm{m}^{2}$ ranging from 0.05 to 0.23 and estimates of $\mathrm{c}^{2}$ ranging from 0.02 to 0.10 (Swan \& Hickson, 1994; Hickson et al., 1995; Mortimer \& Atkins, 1995; Snyman et al., 1996; Cloete et al., 2001; Duguma et al., 2002). With the exception of $\mathrm{h}^{2}$ (which was on the lower limit of these estimates) our results closely resembled those cited above for Merinos.

Positive direct and maternal genetic correlations between birth weight and weaning weight were consistent with those reported by Duguma et al. (2002). Davis (1987a) correspondingly found a positive realised genetic correlation of 0.73 between birth weight and weaning weight. Correlations of birth coat score with birth weight and weaning weight were generally low, and not significant $(\mathrm{P}<0.05)$. No comparable correlations were found in the literature.

Phenotypic means suggested that $\mathrm{H}$ line lambs were heavier at weaning than $\mathrm{L}$ line contemporaries towards the end of the experiment (Figure 2). It was evident that genetic trends diverged for the lines when direct additive breeding values were derived (Figure 3), suggesting that a correlated response in lamb weaning weight is likely when selection is based on ewe multiple rearing ability. The relatively poor fit obtained in the case of the downward trend for the L line (see Figure 3) may be related to smaller numbers of lambs contributing to annual means for predicted breeding values in the $\mathrm{L}$ line as the years progressed. The result pertaining to the genetic divergence between the $\mathrm{H}$ and $\mathrm{L}$ lines confirms preliminary findings obtained earlier on the same resource population (Cloete \& Olivier, 1998) as far as direct breeding values were concerned. It is also supported by findings in the Trangie weaning weight selection experiment. Selection for lamb weaning weight resulted in positive realised genetic correlations for components of reproduction (Davis, 1987a). These correlations were particularly high for lamb survival, ewe rearing ability and number of lambs weaned per ewe joined. These traits are closely related to the selection objective strived for in the present study. Genetic parameters derived for weaning weight, number of lambs weaned and total weight of lamb weaned in three South African Merino studs also support the present results (Olivier et al., 2001). When maternal breeding values were considered, it was evident that the maternal ability of L line animals for weaning weight declined with time. No such conclusive trend was discernable in the $\mathrm{H}$ line. No comparable results on this topic were found in the available literature.

\section{Conclusions}

No marked correlated responses in birth weight and birth coat score resulting from divergent selection for multiple rearing ability were observed. Selection, however, resulted in a correlated change in lamb weaning weight, a trait which indicates the quality of the lambs produced (Olivier, 1999). The study supports research findings that no antagonism exists between the ability of ewes to rear lambs and the quality of the lambs produced (Olivier et al., 2001).

\section{Acknowledgements}

We wish to thank all those responsible for the maintenance and recording of the experimental animals (E. du Toit at Tygerhoek as well as J.E. Fourie and A.J. Scholtz at Elsenburg). The maintenance of the animals was partially enabled by a grant from the SA Wool Industry.

\section{References}

Alexander, G., 1964. Lamb survival: physiological considerations. Proc. Aust. Soc. Anim. Sci. 5, 113-122.

Cloete, S.W.P., 2002. Studies on the behavioural and genetic aspects of ewe rearing ability and lamb survival in South African sheep flocks. Ph.D. dissertation, University of the Free State, Bloemfontein, South Africa.

Cloete, S.W.P., Greeff, J.C. \& Lewer, R.P., 2001. Environmental and genetic aspects of survival an early liveweight in Western Australian sheep. S. Afr. J. Anim. Sci. 31, 123-129.

Cloete, S.W.P. \& Olivier, J.J., 1998. Direct and correlated responses to selection for multiple rearing ability in South Afrcan Merinos. Proc. Ann. Congr. S. Afr. Soc. Anim. Sci. 36, 65-68.

Cloete, S.W.P. \& Scholtz, A.J., 1998. Lamb survival in relation to lambing and neonatal behaviour in medium wool Merino lines divergently selected for multiple rearing ability. Aust. J. Exp. Agric. 38, 801-811.

Cloete, S.W.P., Scholtz, A.J., Franck, F. \& Durand, A., 1994. Diereproduksie- en weidingsparameters vir herfs- en winterlamseisoene in die Swartland. Elsenburg J. 1994. pp. 1-6.

Cloete, S.W.P., Van Niekerk, F.E. \& Rust, J.M., 1998. Application of embryo transfer for the improvement of multiple rearing ability in medium wool Merino ewes. Sheep \& Goat Res. J. 14, 11-12. 
Davies, H.L., 1964. Lamb losses in south-western Australia. Proc. Aust. Soc. Anim. Prod. 5, 107-112.

Davis, G.P., 1987a. Direct and correlated responses to selection on weaning weight in Merinos. Proc. Aust. Assoc. Anim. Breed. Genet. 7, 83-86.

Davis, G.P., 1987b. Genetic relationships between lamb growth and lifetime productivity in Merino sheep. Ph.D. dissertation, University of New England, Australia.

Duguma, G.J., Schoeman, S.J., Cloete, S.W.P. \& Jordaan, G.F., 2002. Genetic parameter estimates of early growth traits in the Tygerhoek Merino flock. S. Afr. J. Anim. Sci. 32, 66-75.

Gilmour, A.R., Cullis, B.R., Welham, S.J. \& Thompson, R., 1999. ASREML - Reference manuel. NSW Agriculture Biometric Bull. No. 3. NSW Agriculture, Orange Agricultural Institute, Forest Road, Orange 2800, NSW, Australia.

Gregory, I.P., 1982. Genetic studies of South Australian Merino sheep. III. Heritabilities of various wool and body traits. Aust. J. Agric. Res. 33, 355-362.

Hickson, J.D., Swan, A.A., Kinghorn, B.P. \& Piper, L.R., 1995. Maternal effects at different ages in Merino sheep. Proc. Aust. Assoc. Anim. Breed. Genet. 11, 416-420.

Kemper, K.E., Smith, J.L. \& Purvis, I.W., 2003. The value of birth coat score as an early selection criterion for superfine Merino sheep. Proc. Assoc. Advmnt Anim. Breed. Genet. 15, 139-142.

Lewis, R.M. \& Beatson, P.R., 1999. Choosing maternal effect models to estimate (co)variances for live and fleece weight in New Zealand Coopworth sheep. Livest. Prod. Sci. 58, 137-150.

Meyer, K., 1989. Restricted maximum likelihood to estimate variance components for animal models with several random effects using a derivative free algorithm. Genet. Select. Evol. 21, 317-340.

Morley, F.H.W., 1955. Selection for economic characters in Australian Merino sheep. V. Further estimates of phenotypic and genetic parameters. Aust. J. Agric. Res. 6, 77-90.

Mortimer, S.I. \& Atkins, K.D., 1995. Maternal effects influence growth traits in Merino sheep. Proc. Aust. Assoc. Anim. Breed. Genet. 11, 421-424.

Mullaney, P.D., 1966. The relation of birth coat and lamb survival. Aust. J Exp. Agric. Anim. Husb. 6, 8487.

Obst, J.M. \& Evans, J.V., 1970. Genotype-environment interactions in lamb survival with particular reference to birth coat and haemoglobin type. Proc. Aust. Soc. Anim. Prod. 8, 149-153.

Olivier, J.J., 1996. Bydrae van voorkomseienskappe ter bereiking van seleksiedoelwitte. In: Seleksiedoelwitte vir Merinos, Aanbevelings voortspruited uit 'n simposium op initiatief van die MerinoOntwikkelingskomitee van Streek I. Reds Cloete, S.W.P. \& Coetzee, J. bls. 43-55.

Olivier, J.J., 1999. The South African Merino performance testing scheme. Proc. Assoc. Advmnt Anim. Breed. Genet. 13, 119-124.

Olivier, W.J., Snyman, M.A., Olivier, J.J., Van Wyk, J.B. \& Erasmus, G.J., 2001. Direct and correlated responses to selection for total weight of lamb weaned in Merino sheep. S. Afr. J. Anim. Sci. 31, 115121.

Ponzoni, R.W., Grimson, R.J., Jaensch, K.S., Smith, D.H. \& Hynd, P.I., 1996. Birth coat: is it worth taking it into consideration in Merino sheep genetic improvement programs? Demands of wool and wool growers beyond 2000. SARDI Research Report Series, No 11. pp. 44-60.

Purser, A.F. \& Karam, H.A., 1967. Lamb survival, growth and fleece production in relation to birth coat type among Welsh Mountain sheep. Anim. Prod. 9, 75-85.

Snyman, M.A., Erasmus, G.J. \& van Wyk, J.B., 1995. Direct and maternal (co)variance components and heritability estimates for body weight at different ages and fleece traits in Afrino sheep. Livest. Prod. Sci. 44, 229-235.

Snyman, M.A., Olivier, J.J. \& Olivier, W.J., 1996. Variance components and genetic parameters for body weight and fleece traits of Merino sheep in an arid environment. S. Afr. J. Anim. Sci. 26, 11-14.

Swan, A.A. \& Hickson, J.D., 1994. Maternal effects in Australian Merinos. Proc. $5^{\text {th }}$ World Cong. Genet. Appl. Livest. Prod. 18, 143-146.

Van der Merwe, C.A. 1976. 'n Studie van kuddestatistieke, teeltstruktuur, genetiese en fenotipiese aspekte van die Elsenburg Dormerkudde. Ph.D.-proefskrif, Universiteit van Stellenbosch, Suid-Afrika.

Verbyla, A.P., Cullis, B.R., Kenward, M.G. \& Welham, S.J., 1999. The analysis of designed experiments and longitudinal data using smoothing splines. J. Royal Stat. Soc., Series C 48, 269-311. 